3. заключение агентских договоров осуществляется на уровне локальных нормативных актов организаций, которые регулируют деятельность спортивных агентов, и общих положений об агентском договоре ГК РФ, что является недостаточным, так как отсутствует единые, специальные требования к компетенции спортивных агентов, а также к порядку заключения агентских договоров на законодательном уровне.

Таким образом, необходимо в законе о профессиональном спорте в РФ установить единые, специальные требования к деятельности спортивных агентов, закрепив основные положения, которые мы перечислили выше.

$$
* * *
$$

1. Гражданский кодекс Российской Федерации (часть вторая) от 26 января 1996 № 14-Ф3 (ред. от 16.12.2019) // Собрание законодательства РФ. 1996. № 5.

2. О физической культуре и спорте в Российской Федерации: Федеральный закон РФ от 04.12.2007 № 329-Ф3 (ред. От 30.12.2020) // Собрание законодательства РФ. 2007.№ 50. Ст. 6242.

3. Положение о деятельности хоккейных агентов: утв. Правлением ФХР (Протокол от 12 марта 2018 г. № 2/18), Советом директоров ООО «КХЛ» (Протокол от 23 марта 2018 г. № 82). Москва. 2018. URL: https://fhr.ru/hockey-of-russia/docs/agents/ (дата обращения 15.03.2021).

4. Апелляционное определение Самарского областного суда от 16.07.2020 по делу N 33-6974/2020, 279/2020. Документ опубликован не был [Электронный ресурс]. Доступ из СПС «КонсультантПлюс» (дата обращения: 18.03.2020).

5. Тащиян А.А., Демьянова Л.М., Дьяченко Е.А. Регулирование агентской деятельности в сфере спорта на корпоративном уровне // Северо-кавказский юридический вестник. 2019.№ 2. С. 112119.

\title{
Мифтахов А.М. \\ Теоретические и практические аспекты пользы для общества от соблюдения правовых положений ислама, запрещающих ростовщичество
}

Болгарская исламская академия (Россия, Болгар)

doi: $10.18411 / \mathrm{j}-08-2021-134$

\section{Аннотация}

Статья посвящена рассмотрению вопросов, связанных с теоретическими и практическими аспектами пользы для общества от соблюдения правовых положений ислама, запрещающих ростовщичество. Автор рассматривает правовое содержание запрета ростовщичества в Исламе. Особое внимание уделяется возможности заимствования в российское право опыта из мусульманского права, связанного с запретом ростовщичества. Автор также акцентирует внимание на проблемных вопросах по теме исследования.

Ключевые слова: ростовщичество, исламский банк, исламская экономическая модель, Россия.

\section{Abstract}

The article is devoted to the consideration of issues related to the theoretical and practical aspects of the benefits for society from observing the legal provisions of Islam that prohibit usury. The author examines the legal content of the prohibition of usury in Islam. Special attention is paid to the possibility of borrowing experience from Muslim law related to the prohibition of usury into Russian law. The author also focuses on problematic issues on the topic of the study.

Keywords: usury, Islamic bank, Islamic economic model, Russia.

В период мирового финансово-экономического кризиса 2008-2009 гг. многие экономисты, ученые, политики заговорили о важности социальной справедливости, о 
формировании новой финансовой модели, обратившись к опыту исламских банков стран Ближнего Востока, вопреки всем законам кризиса показавшие устойчивый рост.

Традиционные финансовые институты ставят своей целью получение максимальной прибыли, тогда как исламские - находят равновесие между религией и бизнесом. Как известно, ростовщичество (риба) категорически осуждается Кораном: «Аллах разрешил торговлю и запретил ростовщичество» $(2: 275)$, «О вы, которые уверовали! Не пожирайте лихву (не занимайтесь ростовщичеством) в многократном умноженном размере и остерегайтесь наказания Аллаха...» (3:130) (Коран, 1991 [3]) [4, c. 76].

Действующий глава Католической церкви также не раз выражал неприятие современной денежно-кредитной политики. Так, в Обращении Его Святейшества Папы Франциска к членам Национального Совета Антиростовщических Фондов от 03.02.2018 находим следующие слова: «Ростовщичество унижает и убивает. Ростовщичество - это древнее и, к сожалению, все еще сокрытое зло, которое, как змея, душит своих жертв. Оно должно быть предотвращено путем устранения патологии накопления людьми долгов для спасения себя и своего бизнеса... В основе экономических и финансовых кризисов всегда лежит та концепция жизни, которая ставит на первое место прибыль, а не человека. Человеческое достоинство, этика, солидарность и общее благо всегда должны быть в центре экономической политики государственных учреждений... Ростовщичество является серьезным грехом: оно убивает жизнь, попирает достоинство людей, выступает средством коррупции и препятствует общему благу. Оно также ослабляет социальные и экономические основы страны. На самом деле, с таким количеством бедных людей, многими семьямидолжниками... ни одна страна не может планировать серьезное экономическое восстановление или даже чувствовать себя в безопасности... Я призываю вас вступить в диалог с теми, кто несет ответственность в области экономики и финансов, с тем, чтобы можно было продвигать инициативы, которые помогают предотвратить ростовщичество» $[5$, с. 704$]$.

На сегодняшний день вместо ссудного процента исламские банки предлагают альтернативные методы финансирования, основанные на реальных активах, партнерстве и справедливом распределении финансовых результатов. Финансирование за счет собственных средств или прямое участие в капитале представляет собой основу исламской экономической системы. В последние годы все чаще высказывается мнение, что подобное финансирование - будущее корпоративных финансов в противоположность «европейскому» долговому финансированию с фиксированным доходом [2, с. 45]. Кроме того, запрещены сделки, в которых много неопределенности в отношении предмета договора и присущ чрезмерный риск, отсюда запрет на операции с производными финансовыми инструментами (опционы, фьючерсы, свопы), применение традиционного страхования и выпуска облигаций. Также исламские банки не финансируют неэтические виды бизнеса (распространение наркотиков, производство алкоголя, табака, игорный бизнес и т.п.). Отдельные исламские банки предоставляют специфический финансовый инструмент «кард-аль-хасан» беспроцентные денежные средства малоимущим, выданные из чувства сострадания, а также проводят активную социальную политику, выдавая денежные средства на различные благотворительные цели, инфраструктурные проекты и образование $[1, \mathrm{c}$. 260].

Ключевым отличием исламских экономических институтов от традиционных является то, что в своей деятельности они помимо законодательных актов руководствуются морально-этическим кодексом, основанным на предписаниях религии, поэтому исламские ценности нашли отражение в ведении бизнеса не только в странах мусульманского мира, но и далеко за его пределами: Европе, Америке, Австралии, Азии и Африке. 
Распространение деятельности исламских финансовых институтов в Российской Федерации незначительно и стало развиваться сравнительно недавно. Внимание к использованию механизмов исламского финансирования заметно усилилось в 2014 г., когда рядом западных стран были введены финансово-экономические санкции, ограничивающие доступ на рынок капитала для многих российских банков и компаний. В этой связи развитие связей со странами исламского мира в торговой, экономической, финансовой и инвестиционной сферах является одним из важных направлений деятельности нашей страны.

О возросшем интересе Российской Федерации к исламским финансам свидетельствует проведение различных круглых столов, семинаров, дискуссий по данной проблематике. В июне 2016 г. на экономическом факультете МГУ имени М.В. Ломоносова состоялся семинар «Актуальные проблемы исламской финансовой модели», в котором приняли участие представители Банка России, Внешэкономбанка, ведущих российских университетов, а также представитель Исламского банка развития. В декабре 2016 г. в МГЮА имени Кутафина прошла межвузовская конференция на тему: «Партнерский банкинг: проблемы правового регулирования, защиты прав участников, перспективы внедрения». В январе 2017 г. в рамках Гайдаровского форума прошла экспертная дискуссия на тему «Исламские финансы: опыт и перспективы», на котором российские и зарубежные эксперты обсудили актуальные вопросы развития исламских финансовых институтов [4, с. 79].

Нельзя не отметить, что применение механизма риба является ярким примером ведения бизнеса по схеме «деньги - деньги - деньги», что отражает основной принцип современной финансовой системы «деньги должны делать деньги». Подобное ведение бизнеса является прямым противоречием нормальной и справедливой схеме «товар - деньги - товар». Это по своей сути приводит к чистому спекулятивному поведению, когда доход создается из ничего, без приложения каких-либо реальных усилий и принесения блага (пользы) обществу в виде товара или услуги, что само по себе противоречит нормальной концепции развития экономики.

Ростовщичество оказывает пагубное развитие на весь мир, поскольку тормозит развитие экономики, служит основой несправедливости, неравенства и нечестия. Это не может не повлечь за собой последствий, которые усложнят и обременят жизнь тех, кто занимается или участвует в этом процессе. Так, ростовщичество влечет и увеличение цен.

Польза нормы, запрещающей ростовщичество, заключается в следующем:

1) Положительное влияние на экономическое развитие страны. Так, проценты на основе финансов не допускаются. В таком случае объем сбережений в основном зависит от дохода. Если доход возрастает, сбережения будут расти независимо от уровня процентной ставки. Мотивы сбережения по большей части не связаны с процентной ставкой;

2) Ростовщичество фактически делает людей добровольными рабами. Представляется, что для современного уровня развития страны это недопустимо;

3) Ростовщичество противоречит концепциям богатства, труда и свободы;

4) Ростовщичество сопряжено с риском десоциализации, социальной изоляции ростовщика и понижением его правового статуса.

Имеются и иные негативные тенденции ростовщичества, которые указывают на необходимость соблюдения правовых положений, запрещающих ростовщичество. И делать это нужно безотлагательно, пока «черный» рынок займов, выпестованный теневыми ростовщиками, на фоне ослабления банковской системы и ее монополистически-уродливой трансформации не стал доминирующим элементом российского общества. По нашему убеждению, в истории российского банковского 
дела наступило время принятия жестких регулирующих правил и действий со стороны полномочных государственных органов по ограничению ростовщических процентных ставок. Коммерческие банки и иные финансовые институты должны устанавливать проценты только в тех размерах, которые компенсируют их издержки, учитывают инфляцию и объективные риски, а также возможность получения прибыли, средней по отраслям экономики. Все, что выходит за рамки «нормального» процента, (привязанного к ключевой ставке, заимствованного из законов Российской империи, рассчитанного иным объективным путем), отражает аморальную природу ростовщичества и подлежит более пристальному вниманию со стороны органов государственной власти и регулятора в лице Банка России.

Таким образом, регулирование и развитие отрасли исламских финансов в России имеет непреходящее значение для привлечения дополнительных инвестиций из стран Ближнего Востока и Юго-Восточной Азии в экономику нашей страны в условиях сложной геополитической ситуации. С появлением нового источника инвестиций возникнут новые финансовые организации, специализирующиеся на исламских финансах, что будет способствовать усилению конкуренции и оздоровлению финансовой сферы.

России предстоит смоделировать финансовое будущее в целях повышения кредита доверия граждан и потенциальных инвесторов к внутриэкономическому курсу страны. Создание альтернативной финансовой системы с учетом опыта лучших исламских банковских практик может заложить прочный фундамент для развития инновационной парадигмы банковского финансирования, распространяющейся в направлении Восток - Запад. Для этого необходимо запустить процесс становления финансовой экосистемы, основанной на доверии в значении negozi di fiducia (ит.) и Vertrauensgeschäfte (нем.). Это даст возможность коммерческим банкам при вступлении в финансовые правоотношения действовать не только с позиций homo economicus, но и с позиций homo fiduciarius.

На сегодняшний день преградой на пути к формированию аналогичных структур в России является российское законодательство, которое не только регулируют, но и поощряют исключительно ростовщическую банковскую деятельность. В связи с этим предполагаем, что в целях развития внутренних инвестиций наиболее оптимальный путь - это принятие федерального закона, регламентирующего инвестиционнодоверительную банковскую деятельность, что позволит создать два сектора (процентный и беспроцентный) и отграничить кредитные (конвенциональные) коммерческие банки, специализирующиеся на процентно-спекулятивной банковской деятельности, от коммерческих банков, специализирующихся на неспекулятивной банковской деятельности по исламской банковской модели.

На наш взгляд, органичный способ обогащения национального банковского законодательства опытом зарубежных юрисдикций представляет собой кратчайший путь для его модернизации, что важно в условиях быстро меняющегося мира и способствует трансферу компетенций.

$$
* * *
$$

1. Абдулкаримова Н.З., Магомедова С.И., Эльмурзаева И.Х. Теоретические и базовые предпосылки развития исламской экономической доктрины: предписания в Коране и Сунне // В сборнике: Духовное наследие мусульманских богословов в контексте проблем XXI века. 2021. С. 257-264.

2. Зарипов И. Джадидистская экономика: татарские религиозные реформаторы начала XX в. о ростовщичестве и банках // Государство, религия, Церковь в России и за рубежом. 2018. Т. 36. № 3. С. $42-59$.

3. Коран [Электронный ресурс] // https://librebook.me/quran/vol1/1 (дата обращения: 09.07.2021).

4. Мусаев Р.А., Магомедова Ю.Д. Исламская экономическая модель: сущность и перспективы развития в России // Россия и Азия. 2018. № 2 (3). С. 75-80.

5. Редькин О.И., Рудоквас А.Д., Тенберга И. Инвестиционные технологии исламских банков и перспективы становления беспроцентного банковского сектора в России // Правоведение. 2018. Т. 62. № 4. С. 692-713. 